University of South Florida

DIGITAL COMMONS

Digital Commons @ University of

@ UNIVERSITY OF SOUTH FLORIDA

South Florida

School of Geosciences Faculty and Staff

Publications

School of Geosciences

$12-2015$

\title{
Who will Build the 21st Century?: Addressing Critical Demographic Gaps in the Geosciences
}

\author{
Bradley Cramer \\ University of lowa \\ Katherine J. Lewandowski \\ Eastern Illinois University \\ Arthur Goldstein \\ Bridgewater State University \\ Pranoti Asher \\ American Geophysical Union \\ Jeffrey G. Ryan \\ University of South Florida, ryan@usf.edu
}

See next page for additional authors

Follow this and additional works at: https://digitalcommons.usf.edu/geo_facpub

\begin{abstract}
Scholar Commons Citation
Cramer, Bradley; Lewandowski, Katherine J.; Goldstein, Arthur; Asher, Pranoti; Ryan, Jeffrey G.; Schofield, David I.; and Buchanan, Rex, "Who will Build the 21st Century?: Addressing Critical Demographic Gaps in the Geosciences" (2015). School of Geosciences Faculty and Staff Publications. 1131.

https://digitalcommons.usf.edu/geo_facpub/1131
\end{abstract}

This Article is brought to you for free and open access by the School of Geosciences at Digital Commons @ University of South Florida. It has been accepted for inclusion in School of Geosciences Faculty and Staff Publications by an authorized administrator of Digital Commons @ University of South Florida. For more information, please contact digitalcommons@usf.edu. 


\section{Authors}

Bradley Cramer, Katherine J. Lewandowski, Arthur Goldstein, Pranoti Asher, Jeffrey G. Ryan, David I.

Schofield, and Rex Buchanan 


\section{Who will build the 21st century? Addressing critical demographic gaps in the geosciences}

Bradley D. Cramer, Dept. of Earth and Environmental Sciences, University of lowa, lowa City, lowa 52242, USA, bradley-cramer@ uiowa.edu; Katherine J. Lewandowski, Dept. of Geology/ Geography, Eastern Illinois University, Charleston, Illinois 61920, USA, kjlewandowski@eiu.edu; Arthur Goldstein, Bartlett College of Science \& Mathematics, Bridgewater State University, Bridgewater, Massachusetts 02325, USA, arthur.goldstein@ bridgew.edu; Pranoti Asher, American Geophysical Union, Washington, D.C. 20009, USA, pasher@agu.org; Jeffrey Ryan, School of Geosciences, University of South Florida, Tampa, Florida 33620, USA, ryan@usf.edu; David I. Schofield, British Geological Survey, Greenmeadow Springs, Tongwynlais, Cardiff CF15 7NE, UK, dis@bgs.ac.uk; Rex Buchanan, Kansas Geological Survey, University of Kansas, Lawrence, Kansas 66047, USA, rex@ kgs.ku.edu; Richard Denne, Marathon Oil, Houston, Texas 77056, USA, radenne@marathonoil.com; William I. Ausich, School of Earth Sciences, The Ohio State University, Columbus, Ohio 43210, USA, ausich.1@osu.edu; Thijs R.A.Vandenbroucke,Evo-EcoPaleo, UMR 8198 du CNRS, Université Lille 1, Villeneuve d'Ascq 59655, France, and Dept. of Geology and Soil Sciences, Ghent University, Ghent 9000, Belgium, Thijs.Vandenbroucke@UGent.be; Sherman Lundy, BMC Aggregates L.C., Elk Run Heights, lowa, 50707, USA, sherm/@bmcaggregates.com; Tyler Priest, Dept. of History and Dept. of Geographical and Sustainability Sciences, University of lowa, lowa City, lowa 52242, USA, tyler-priest@ uiowa.edu; and Ryan J. Clark, lowa Geological Survey, University of lowa, lowa City, lowa 52242, USA, ryan-j-clark@uiowa.edu

\section{INTRODUCTION}

The geoscience workforce in the United States may be facing a critical shortage of trained personnel (Gonzalez and Keane, 2011; NRC, 2013; Mosher et al., 2014; Wilson, 2014a). The National Bureau of Labor Statistics projects a $16 \%$ increase in geoscience jobs by 2022. If, as projected, more than half of the present geoscience workforce retires by that time (Wilson, 2014a, 2014b), up to 185,000 new geoscientists will be needed. Graduation rates in U.S. geoscience programs (Wilson, 2014a) are slowly increasing but still lack the capacity to produce such numbers by 2022 (Fig. 1A). The result is a projected shortfall of 135,000 trained geoscientists within the next decade (Wilson, 2014a, 2014b). To meet these growing challenges to our ability to research, assess, and utilize our natural resources in an environmentally responsible manner, we must increase the number of geoscience students.

\section{RECENT PROGRESS}

The National Research Council (NRC) and National Science Foundation (NSF) addressed the impending shortage of geoscientists (NRC, 2013; Mosher et al., 2014) in the context of federal funding and undergraduate education (Fig. 1A). The NRC identified a three-tiered framework, Awareness, Engagement, and Professional Preparation, as steps in the process of training the next generation of geoscientists and suggested a "System Approach" to coordination of existing federal funding (NRC, 2013). The NRC called for better connections among Federal agencies, academic institutions, and professional societies to clarify educational and training pathways, as well as the need to collect more and better data on which programs are successful and why, with a focus on critical incident analysis as a means of understanding what brings students into the geosciences.

The recent NSF-supported Summit on the Future of Undergraduate Geoscience Education (Mosher et al., 2014) focused on Curriculum and Competencies, Pedagogy/Technology, and Underrepresented Groups. Participants agreed that the next generation of geoscience students needs to approach the field as the applied sum of all sciences (Mosher et al., 2014) and effectively communicate across disciplines as well as with the public. The K-12 Next Generation Science Standards can help develop these skills, but most school districts lack teachers with geoscience training, and most students will never take a K-12 geoscience course (Wilson, 2014a, 2014c; LaDue and Brown Manning, 2015). Of particular concern is how poorly the geosciences have recruited and retained students from underrepresented groups (Fig. 1B; Wilson, 2014a). Workforce data demonstrate that students exposed to $\mathrm{K}-12$ geoscience are more likely to pursue geoscience degrees (Wilson, 2014a). Therefore, expanded opportunities and support for underrepresented students at all levels, as well as expanded opportunities for $\mathrm{K}-12$ teacher training in the geosciences (LaDue and Brown Manning, 2015), are critical to rebuilding the geoscience workforce.

\section{INCREASING CAPACITY}

Nearly half of all students receiving a geoscience degree decide to become a geoscientist at some point after their first year of undergraduate education (Wilson, 2014c). Considered in light of the growing numbers of students who enter higher education at two-year colleges, the transition between two-year and four-year institutions is critical to expanding the geoscience student pipeline. Entry-level courses need to highlight the geosciences as a potential career path. These upstream improvements in awareness must include efforts to engage underrepresented students by recruiting them into introductory courses and providing mentorship and research opportunities in pursuit of geoscience degrees.

Undergraduate geoscience student enrollments are increasing (Wilson, 2014a); however, undergraduate and graduate professional training opportunities are relatively stagnant or even 


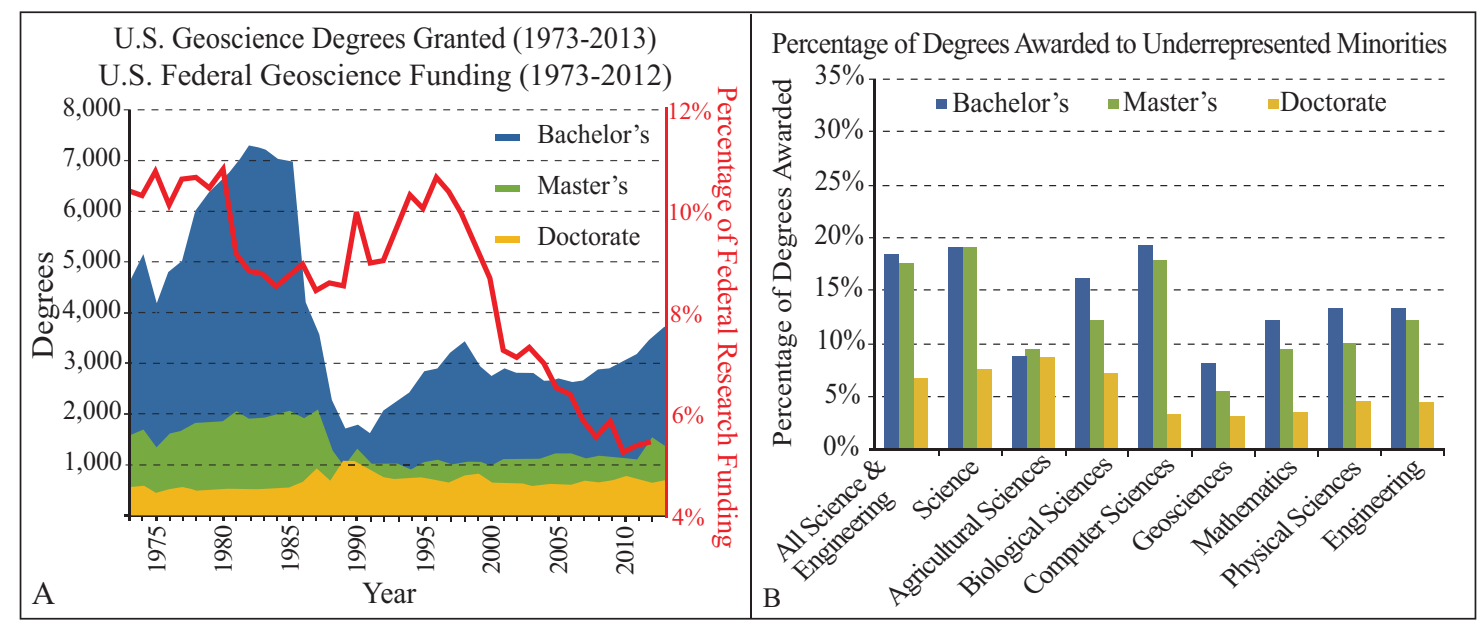

Figure 1. (A) Geoscience degrees granted by year and U.S. federalffunding of geoscience as a percentage of total research spending. (B) Percentage of degrees awarded to underrepresented minorities. Data and figures from the American Geosciences Institute (Wilson, 2014a).

contracting. Student numbers in field camps are up nationwide, yet the number of universities offering field camps has declined by 60\% since 1995 (Petcovic et al., 2014). Many universities offer anecdotal evidence that the number of applicants to geoscience graduate programs is increasing, yet the number of funded graduate student positions available has not kept pace. The M.S. degree is the "working" degree in the geosciences, but decades ago a trend began to remove M.S. programs to focus exclusively on Ph.D. programs, applying further pressure on the number of funded graduate student positions available. Increases in the number of students entering the upstream end of the geoscientist pipeline must be matched by growth in opportunities for advanced and graduate training downstream in the form of graduate funding, mentorship, and field and research opportunities.

Participation in the process of science (LaDue and Brown Manning, 2015) is critical to training the next generation of geoscientists, and more than half of all geoscience undergraduate students participate in some form of faculty-directed research (Wilson, 2014c). However, the average age of geoscience faculty in the U.S. is 60 years (Wilson, 2014a). As with industry, the lack of younger personnel is threatening the ability to train future students in key disciplines of the geosciences. This problem is exemplified by the looming extinction of paleontology in both academia and industry (Saucier, 2015). We must maintain our ability to train the future geoscience workforce by rebuilding the aging academic workforce.

\section{SELF-IDENTIFICATION \& COMPETENCIES}

Student specialization, and increased social self-identification with that specialty, often comes increasingly early in academic careers. Students self-identifying as specialists, instead of geoscientists, leads to an increasingly narrow focus of study. Instead of embracing the interrelated facets of geology, early-career students are frequently advised to specialize at the expense of expanding their potential interests in disciplines they may not encounter early on. Furthermore, such specialization limits their core competencies and their ability to cross-train others in the future. Increased student specialization must be matched by mentorship that advocates for multidisciplinary research activities.

Colleges and universities can help bridge the gap between geoscience education and training objectives and end-user competencies by reengaging their alumni. Competency objectives should be driven by the eventual employers of geoscience students (both public and private), not exclusively by geoscience departments. Academia is just one of the professions in which geologists find employment, and it is critical that we expose students to other voices and perspectives early and often during their education if we are to rebuild the geoscience workforce.

\section{ACKNOWLEDGMENTS}

We thank G. Dickens (editor), J. Geissman, B. Thomas, and an anonymous reviewer for comments that significantly strengthened this manuscript. This work is the outcome of a 2014 International Geoscience Programme (IGCP) Project 591 Public Policy Symposium at the University of Iowa. Travel funding was provided by a Stanley Major Projects Award, International Programs, University of Iowa.

\section{REFERENCES CITED}

Gonzalez, L., and Keane, C., 2011, Status of the geoscience workforce 2011: Washington, D.C., American Geosciences Institute, 190 p., http://www .americangeosciences.org/sites/default/files/ StatusoftheWorkforce2011 loverview.pdf (last accessed 1 Oct. 2015).

LaDue, N.D., and Brown Manning, C., 2015, Next Generation Science Standards: A call to action for the geoscience community: GSA Today, v. 25, no. 2, p. 28-29, doi: 10.1130/GSATG233GW.1.

Mosher, S., Bralower, T., Huntoon, J., Lea, P., McConnell, D., Miller, K., Ryan, J., Summa, L., Villalobos, J., and White, L., 2014, Summary report for summit on future of geoscience education 10-12 January 2014: University of Texas at Austin, http://www.jsg.utexas.edu/events/files/Future_ Undergrad_Geoscience_Summit_report.pdf (last accessed 1 Oct. 2015).

National Research Council, 2013, Preparing the next generation of earth scientists: An examination of federal education and training programs: Washington, D.C., National Academies Press, 95 p.

Petcovic, H.L., Stokes, A., and Caulkins, J.L., 2014, Geoscientists' perceptions of the value of undergraduate field education: GSA Today, v. 24, no. 7, p. 4-10, doi: 10.1130/GSATG196A.1.

Saucier, H., 2015, Seismic killed the paleo star: AAPG Explorer, v. 36, no. 3, p. $30-34$.

Wilson, C., 2014a, Status of the geoscience workforce 2014, Washington, D.C., American Geosciences Institute, 136 p., http://www.americangeosciences. org/workforce/reports/status-report-2014 (last accessed 1 Oct. 2015).

Wilson, C., 2014b, Explanation of the predicted geoscience workforce shortage: Geoscience Currents no. 93, 16 Oct. 2014, http://www. americangeosciences.org/workforce/currents/explanation-predictedgeoscience-workforce-shortage (last accessed 1 Oct. 2015).

Wilson, C., 2014c, Status of recent geoscience graduates 2014: Washington, D.C., American Geosciences Institute, 44 p, http://www. americangeosciences.org/sites/default/files/cwilson/ExitSurvey_101614_ MedResWithLinks_0.pdf (last accessed 1 Oct. 2015).

Manuscript received 1 Feb. 2015; accepted 9 June 2015. 